\title{
Culture in Second or Foreign Language Acquisition $^{*}$
}

\author{
Rongmei Yu \\ NanChang Normal University, China
}

\begin{abstract}
Many theorists have pointed out that in real world communication, the usage of a language is always colored by a cultural norm so that the language used in communication can be understood by the majority of a cultural community or society. The relationship between language usage and cultural norms or pragmatic rules can never be broken in communication. In cross-cultural communication, the differences in pragmatic rules, communicative strategies, cross-cultural psychology among other may become problematic areas in learning a second or foreign language. Consequently, making the differences known to both learners and teachers is of paramount importance in teaching and learning a second or foreign language. By addressing and discussing some cultural-specific factors in teaching and learning a second or foreign language, this thesis aims to provide useful learning factors in which learners frame meaning in a second or foreign language and thus emphasize the importance of teaching culture to second or foreign language learners, it also tentatively provide some instructional strategies for teaching culture in second or foreign language acquisition (SLA/FLA) classroom.
\end{abstract}

Index Terms - culture, language, SLA, FLA, cross-cultural communication

\section{INTRODUCTION}

Language and culture are closely related. Language is the carrier of culture, and culture is transmitted through language. The presence of Culture representations in a second or foreign language teaching is inevitable. By tradition and necessity, second or foreign language instruction often addresses cultural issues, and teachers who teach English as a second or foreign language are often called upon to explain English-speaking cultures and cultural differences, and to help students adjust to the target culture. No matter how difficult it would be in discussing culture with their students, teachers' views of themselves, their students, teaching curriculum and the relationship among cultures have great impact on teaching outcome. Meanwhile, students' positive and objective attitudes toward the target culture as well as the culture of their own may mostly facilitate SLA/FLA and vice versa. Moreover, a person's world view, beliefs, and presuppositions affected his or her understanding of second culture. These beliefs and presuppositions are of great pedagogical significance in second or foreign language teaching and learning.

\section{Definition of Culture}

The problems of understanding the role of culture in the classroom are made more acute when culture itself is the subject of study. Before discussing cultural-specific or cultural-determinative aspects in SLA/FLA, it is prerequisite for us to know what culture is.

The term "culture" can have different meanings. Some language teachers refer it to literary or architectural works. Others refer it to background information like the history or geography of countries. According to Scollon and Scollon, "culture" has two normal uses in English, i.e. high culture and anthropological culture. High culture, as Scollon and Scollon defined, "focuses on intellectual and artistic achievements." We say that Beijing is a historic and cultural city because it has magnificent ancient palaces and other buildings that are typical in feudal times. "When culture is referred to in its anthropological sense, it means that culture is any of the customs, worldview, language, kinship system, social organization, and other taken-for-granted day-to-day practices of a people which set that group apart as a distinctive group." (Scollon \& Scollon, 2000:p126). It is also proposed that the term of culture may be understood in broad and narrow senses. "It may refer to the intellectual refinement and artistic endeavor, or the appreciation of music, literature, the art, and so on." (Wang Lifei, 2000:p193). This is culture in its broad sense. On the other hand, culture may also refer to whatever a person must know in order to function in a particular society. This is culture in its narrow sense. Bates and Plog's definition belongs to this category. They claim that "culture is a system of shared beliefs, values, customs, behaviors, and artifacts that the members of a society use to cope with their world and with one another, and that are transmitted from generation to generation through learning." (Samovar \& Porter, 1997:p36) Although some scholars and language educators suggested that culture acquisition include both the narrow and broad sense, here we mainly focus on the narrow one.

\footnotetext{
${ }^{*}$ This paper is funded by 11531 project of Nanchang Normal University
} 


\section{RELATIONSHIP BETWEEN LANGUAGE AND CULTURE}

Language is a means of communication in our social lives, and it has an indispensable relationship with culture. Kramsch has proposed that "Culture and language are inseparable and constitute a single universe or domain of experience" (Hinkel, 2001:p6). Language is a symbolic system of human communication and also a part of the conventional culture. The languages are the carrier of cultures, so a society's language is an aspect of its culture. Culture and language influence each other. Every language is part of a culture and every culture is part of a language. As such, language can only reflect cultural needs and no one cannot separate the two without losing the significance of either language or culture. For example, Eskimos have seven different words for snow to distinguish among different types of snow, while African have no word for snow; Chinese has a complex system of kinship terms to distinguish among 叔 叔、舅舅、姑爷、舅父、姑父, and so on while in English these terms have just one tally “uncle”. Examples like these suggest a simple principle that different cultural background produce different linguistic features.

On the other hand, language is the carrier of culture. Language can reinforce and preserve a culture, its beliefs and customs, and sometimes, conditions in its future course of development. As long as a language is in use, the culture it represents will survive. Even if a culture is wiped out, it can still be studied by looking at its language. Culture and language at all time are considered to be two principal and inseparable, if not all identities of a social group, a nation or a state.

\section{THE IMPORTANCE OF CULTURE IN SLA/FLA}

Applied linguists and language teachers believe that in learning and teaching a foreign language, we should make more use of the culture of the language community. According to Schumann's Acculturation Model as a seminal theory of SLA, SLA "is just one aspect of acculturation and the degree to which a learner acculturates to the target language group will control the degree to which he acquires the second language." Based on Schumann's theory, Brown defines acculturation as "the process of becoming adapted to a new culture". That is to say, acculturation is a crucial step which lies within the continuum of SLA, because language is one of the most observable expressions of culture and because in second language (L2) settings the acquisition of a new language is seen as tied to the way in which the learner's community and the target language community view each other (Ellis, 1985:p251). Before we touch upon the importance of culture in SLA/FLA in this paper, one question is paramount for us to get an appropriate answer: What does it mean to know a language? It is now generally accepted by linguists and educators that the factors involved in knowing a language include linguistic competence and communicative competence, and the status of these two facets depends upon whether we adopt a linguistic or sociolinguistic perspective on language. In our discussion, we adopt the latter one. Hymes first introduced the notion of communicative competence that has subsequently had a great deal of influence on second or foreign language research and teaching methodologies. He pointed out that "in addition to our knowledge of rules of grammar, knowing a language entails being able to use it for social and communicative interaction, that is, knowing when it is appropriate to open a conversation and how, what topics are appropriate to particular speech events, which forms of address are to be used, to whom and in which situations, and how such speech acts as greetings, compliments, apologies, invitations and complements are to be given, interpreted and responded to" (Richards, 2001:p145). Byram also pointed out that communicative competence involves appropriate language use which, in part at least, is culture specific." (Hinkel, 2001:p6). From the sociolinguistic views, communicative competence extends beyond linguistic competence and requires learners' context-specific knowledge of interactive practices in a second or foreign culture. To become qualified communicator in a second or foreign culture, learners need to be taught to become sensitive observers, use proper language. Learning to pay attention to interaction can make learners to make well-informed choices of behaviors when they are communicating with members of a second or foreign culture. Still there is an argument that until learner's first cultural identity is established, it may be harmful to learn about other cultures. In this view, it is acceptable for younger students to learn English as a foreign language (EFL) or English as a second language (ESL) but not for them to learn about English-speaking culture. This argument depends on the separability of language and culture, yet, as stated above, many scholars in the field maintain that such separation is impossible and undesirable if communicative competence is the goal. A cultural focus on communicative competence has communicative ends, but there are further important advantages. It may not only encourage the development of language learner's identity but also encourage the awareness of others' identities. Moreover, it is important that second or foreign language learners should know the different cultural frameworks; otherwise they will use their own cultural system to interpret second or foreign language message which is quite different.

\section{LEARNING STYLE AND CULTURE}

So far we have adopted a sociolinguistic perspective to discuss generally the importance of culture in SLA/FLA. Culture is the pervasive phenomenon which affects L2 or foreign language learners in many aspects, and its impact on learning style has been given special attention by language teachers and educators.

\section{A. Definition of Learning Style}

Research has shown that different person vary greatly in the ways they learn a L2 or foreign language. Some learners 
are good at analyzing and breaking down words and sentences, others need to experience the overall pattern of the language in a meaningful context, some focus on the visual, others are more focused on the sound.. According to Reid's definition, learning style "refers to an individual's natural, habitual, and preferred way(s) of absorbing, processing, and retaining new information and skills. These learning styles persist, regardless of teaching methods and content areas." (Reid, 2002:34).

\section{B. Relationship between Learning Style and Culture}

Seeing from the aspect of definition, learning style and culture seem to be at odds. Learning styles focus on individual difference, while culture focuses on what a group of individuals have in common. It is true that culture is shared. Nevertheless, culture is also learned by individuals through the socialization process. People learn how to learn within their cultural circumstance, i.e. the cultural learning styles are learned in families and through other social relationships before children are old enough to attend school.

\section{Cultural-specific Differences between the Learning Styles of Chinese Students and Western Students}

The differences between the learning styles of Chinese students and that of Western students can be partly traced from the distinction between the Confucian and Socratic tradition of education. Dialogue is at the heart of the Socratic method of education, the Western classroom emphasizes the art of rhetoric as a search for knowledge and truth, while in Confucian education, the primary goal is to acquire wisdom and teach students to act in accordance with moral principled. Furthermore, as Scollon emphasizes, that the assumptions of group identity and harmony maintenance, ubiquitous in the cultures that embrace Confucian philosophy, may appear to be a paramount goal for Chinese students operating in their first language or second language that is not necessarily shared in the Western Socratic teaching and learning tradition (Hinkel, 2001:p18).

The Confucian tradition places a high value on education, and particularly on educating the members of society in the ways humans should relate and interact with each other. Confucianism respects age, seniority, rank and family background, and ESL/EFL teachers in China and abroad are particularly interested in the Confucian teacher-student relationship, which is more hierarchical than the Western teacher-student relationship, and teachers are more instructive about what happens in the classroom. In China, the teacher is an authority figure. Confucius taught that the teacher must know all and it is firmly believed by Chinese students especially in primary and middle schools. It is always the case that students are reluctant to raise questions against their teacher in class even if they believe what the teacher has said is problematic and unacceptable. Confucius and his students also modeled a close teacher-student relationship in which teachers, like parents, help students grow into complete and adjusted human beings. On the other hand, Socrates thought of himself as midwife. Just as in the Greek tradition a midwife was required to be past childbearing age, Socrates claimed to be beyond giving birth to brilliant ideas. His role in relationship to his students is to lead them to the truth by means of questioning (ibid., p.19). Therefore the Western teachers nowadays are likely to assign tasks for which the teachers do not take responsibility, students often assume that these tasks are assigned because they have value for their own sake. It is also unsurprisingly that classes become a hot debate among teacher and students so long as disagreement exists.

Another characteristic of Chinese learning style is cooperation. The Chinese preference for cooperation contracts with the Western preference for individualism and competition, a system in which the child is trained to look at the members of his group as constant competitors and urged to make great effort to surpass them. In China, all children are expected to achieve good results; everyone is required to help each other. In the community, people understand each other and sincerely care about each other's happiness. In order to survive in the country where natural resources are limited, members of a community perish the importance of cooperation. Unlike the competition and individualism that motivate Western children, Chinese schooling encourages cooperation almost exclusively. Personal success is meaningful, rewarding and humbly accepted, but those who succeed give credit first to their class, parents, and country, and last to personal success. In Western cultures, one's worth is often based on what one has achieved, and students frequently learn through competition with each other. In China, however, efforts at competition may result in embarrassment and loss of face for the students.

\section{InStructional Strategies For TEAChing Culture in SLA/FLA ClassRoom}

From what have been mentioned above, we can see that second culture acquisition is a crucial sector and predominant goal over linguistic competence in SLA/FLA. As communicative competence is concerned, the aim of second or foreign language teaching is to develop students' communicative competence. Nevertheless, it is argued that merely integrating second language teaching and the culture of its speakers is insufficient for learners to develop communicative competence and social effectiveness. Although research has long recognized a need for teaching materials to facilitate the development of learners' communicative competence, textbooks and methodologies reflect the source and target cultures in ways that lead to mismatches and create obstacles to learning. What constitutes good teaching and learning is often based on the socialization processes and the internalization of roles and expectations that teachers and students take for granted. These are closely interwoven with attitudes, values, and beliefs that underlie the teaching of culture. To be effective and to help students achieve communicative competence, the teaching and the 
learning of culture need to become a dialogue between the source and the target culture. There are several instructional strategies that can be employed to achieve our goals in teaching culture in SLA/FLA.

\section{A. The Introduction of Literature}

Literary texts often contain cultural information and attract reader's memorable reactions. A literary text is the real language in context. It offers exploration and discussion of content and also the examination of language. What you say and how you say it are closely related. And students come to understand and appreciate this. Literary texts provide examples of language resources, and the language learners use the language resources to fulfill their learning goals. i.e. contextually appropriate and linguistically graded, can be very helpful in allowing students to acquire insight into a culture. Moreover, literature teaching can provide the students with rich cultural background knowledge of different nations. It helps the students learn the history, politics, economy, people's habit, customs and moralities. The biggest obstacle in learning a second language is the unfamiliar culture it represents. Literature teaching can solve this problem in the environment of the learned language and can to some degree shorten the distance between the target language and language of the learners' own (Brumfit \& Carter, 2000:p42).

\section{B. The Application of Multi-media}

The application of multi-media to language teaching and learning has provides teachers and students with abundant information of the target language that is taught as a L2 or foreign language. This has significant predominance over the traditional means of language education. For example, film and television make students have an opportunity to witness behaviors that are rarely found in texts. Scollon suggested that film is often one of the more current and comprehensive ways to encapsulate the look, feel, and rhythm of a culture. Film also connects students with language and cultural issues simultaneously, such as depicting conversational timing or turn-taking in conversation. At least one study showed that students achieved significant gains in overall cultural knowledge after watching videos from the target culture in the classroom (Hinkel, 2001:p184).

\section{CONCLUSION}

To summarize, in this paper we have presented speculations and arguments concerning the definition of culture, the relationship between language and culture, and the importance of teaching culture in SLA. We have also provided some instructional strategies concerning culture acquisition in SLA/FLA. We think that learning a second or foreign language is not simply mastering the linguistic systems of a language, rather, it focuses on learning about the culture as a means of communication. Finally, we have to bear in mind the cautionary remark proposed by Hall that "it is necessary not only to study and understand foreign culture which underlies cross-cultural communication, but also to be aware of one's culture so as to learn more about how one's system works, about something useful and enlightening about oneself." (Wang Li fei 2000: p195). Culture and language are such closely interwoven facets in a society that the distinction of one would probably lead another to perdition. A learner cannot totally acquire a language without getting a full understanding of its culture. At the same time, it is inexpedient for those learners who attempt to get rid of his or her mother tongue or culture in the process of SLA/FLA, which means the vanishing of their identities in society.

\section{REFERENCES}

[1] Brumfit, C. J. and R. A. Carter. (2000). Literature and Language Teaching. Shanghai: Shanghai Foreign Language Teaching Press.(2000:42)

[2] Carroll, D. W. (2004). Psychology of Language (3rd Edition). Beijing: Foreign Language Teaching and Research Press.

[3] Cook, Vivian. (2000). Linguistics and Second Language Acquisition. Beijing: Foreign Language Teaching and Research Press.

[4] Cook, Vivian. (2000). Second Language Learning and Language Teaching (2nd Edition). Beijing: Foreign Language Teaching and Research Press.

[5] Ellis, Rod. (1985). Understanding Second Language Acquisition. Oxford: Oxford University Press.( 1985:251)

[6] Freeman, D. L. and M. H. Long. (2000). An Introduction to Second Language Acquisition Research. Beijing: Foreign Language Teaching and Research Press.

[7] Hinkel, Eli (ed.). (2001). Culture in Second Language Teaching and Learning. Shanghai: Shanghai Foreign Language Teaching Press.(2001: P6 /P18 /P 184)

[8] Kramsch, C. (2000). Language and Culture. Shanghai: Shanghai Foreign Language Teaching Press.

[9] Mayes, P. (2002). Language, Social Structure, and Culture. Philadelphia: John Benjamins Publishing Company.

[10] Mckay, S. L. and N. H. Hornberger. (2001). Sociolinguistics and Language Teaching. Shanghai: Shanghai Foreign Language Teaching Press.

[11] Reid, Joy M. (2002). Learning Styles in the ESL/EFL Classroom. Beijing: Foreign Language Teaching and Research Press.( 2002:34)

[12] Richards, Jack C. (2001). The Context of Language Teaching. Beijing: Foreign Language Teaching and Research Press. (2001:145)

[13] Samovar, L. A., Richard E. Porter and Lisa A. Stefani. (1997). Communication Between Cultures (3rd Edition). Cambridge: Wodsworth Publishing Company. (1997:36)

[14] Scollon, Ron and S. W. Scollon. (2000). Intercultural Communication: A Discourse Approach. Beijing: Foreign Language Teaching and Research Press. (2000:126) 
[15] Spolsky, B. (2000). Sociolinguistics. Shanghai: Shanghai Foreign Language Teaching Press.

[16] Wanglifei. (2000). Modern Foreign Language Teaching Theory, Shanghai: Shanghai Education Publishing House (2000 :P193-195)

Rongmei Yu was born in JiangXi province China in 1964. She received her Bachelor's degree in English Language and Literature from JiangXi Normal University, China in 1989.

She is currently a professor in Nan Chang Normal University, JiangXi, China. Her research interests include Intercultural Communication and English Teaching.

Prof. Yu is a member of JiangXi Translation Association and the teacher of Nan Chang Normal University. 